\title{
Bufalin induced apoptosis in SCC-4 human tongue cancer cells by decreasing Bcl-2 and increasing Bax expression via the mitochondria-dependent pathway
}

\author{
HAN-YU CHOU ${ }^{1 *}$, FU-SHIN CHUEH ${ }^{2 *}$, YI-SHIH MA ${ }^{3,4}$, RICK SAI-CHUEN WU $^{5}$, CHING-LUNG LIAO ${ }^{6}$, \\ YUNG-LIN CHU $^{7}$, MING-JEN FAN ${ }^{8,9}$, WEN-WEN HUANG ${ }^{1}$ and JING-GUNG CHUNG ${ }^{1,10}$
}

\begin{abstract}
${ }^{1}$ Department of Biological Science and Technology, China Medical University, Taichung 40402; ${ }^{2}$ Department of Food Nutrition and Health Biotechnology, Asia University, Taichung 41354; ${ }^{3}$ School of Chinese Medicine for Post-Baccalaureate,

I-Shou University, Kaohsiung 84001; ${ }^{4}$ Department of Chinese Medicine, E-Da Hospital, Kaohsiung 82445;

${ }^{5}$ Department of Anesthesiology, China Medical University Hospital; ${ }^{6}$ College of Chinese Medicine, School of Post-Baccalaureate Chinese Medicine, China Medical University, Taichung 40402; ${ }^{7}$ Department of Food Science, International College, National Pingtung University of Science and Technology, Pingtung 912; ${ }^{8}$ Department of Biotechnology, Asia University, Taichung 41354; ${ }^{9}$ Department of Medical Research, China Medical University, Taichung 40402;

${ }^{10}$ Department of Biotechnology, Asia University, Taichung 41354, Taiwan, R.O.C.
\end{abstract}

Received July 31, 2016; Accepted July 17, 2017

DOI: $10.3892 / \mathrm{mmr} .2017 .7651$

\begin{abstract}
The aim of the present study was to investigate the cytotoxic effects of bufalin on SCC-4 human tongue cancer cells. Cell morphological changes and viability were examined using phase contrast microscopy and flow cytometry, respectively. The results indicated that bufalin induced morphological changes and reduced total viable cells. Apoptotic cell death was analyzed by DAPI staining and DNA gel electrophoresis; the results revealed that bufalin induced cell apoptosis. Levels of reactive oxygen species (ROS), $\mathrm{Ca}^{2+}$, nitric oxide (NO) and mitochondrial membrane potential $\left(\Delta \Psi_{\mathrm{m}}\right)$ were measured by flow cytometry, and bufalin was observed to increase $\mathrm{Ca}^{2+}$ and NO production, decrease the $\Delta \Psi_{\mathrm{m}}$ and reduce ROS production in SCC-4 cells. In addition, western blotting was performed to detect apoptosis-associated protein expression. The results demonstrated that bufalin reduced the expression of the anti-apoptotic protein B-cell lymphoma 2 (Bcl-2) and increased the expression of the pro-apoptotic protein, Bcl-2-associated X protein. However, bufalin treatment also increased the expression of other apoptosis-associated
\end{abstract}

Correspondence to: Professor Jing-Gung Chung or Dr Wen-Wen Huang, Department of Biological Science and Technology, China Medical University, 91 Hsueh-Shih Road, Taichung 40402, Taiwan, R.O.C.

E-mail: jgchung@mail.cmu.edu.tw

E-mail:wwhuang@mail.cmu.edu.tw

*Contributed equally

Key words: bufalin, mitochondria, DNA ladder, apoptosis, SCC-4 cells proteins such as apoptosis-inducing factor and endonuclease $\mathrm{G}$ in SCC-4 cells. Based on these findings, bufalin may induce apoptotic cell death via mitochondria-dependent pathways in human tongue cancer SCC-4 cells.

\section{Introduction}

Oral cancer is one of the major causes of cancer-associated mortalities in the global human population and the total number of patients with oral cancer who are younger than 40 years old has markedly increased in the last decade (1). In Taiwan, a report by the Department of Health in 2014 (2) demonstrated that there are 36.8 mortalities per 100,000 people associated with oral cancer every year. During the early stages of oral cancer patients are mainly treated with surgery, which is occasionally coupled with radiotherapy; however, as it becomes more advanced a combination of surgery, radiotherapy and chemotherapy is applied, which can have adverse effects on the patients' quality of life $(3,4)$. Currently, there are a number of clinically used chemotherapeutic drugs that have been approved for the treatment of oral cancer, including cisplatin, cetuximab and endothelial growth factor receptor (EGFR) inhibitors (5). However, the development of more effective treatments and drugs with lower toxicities is required in order to improve patient prognosis and reduce the number of oral cancer-associated mortalities.

Bufalin, a small molecular compound, was isolated from chansu, a traditional Chinese medicine (TCM) that was obtained from the skin and parotid glands of the Chusan Island toad (Bufo gargarizans) (6). The extract from chansu has been used as a TCM to treat various types of cancers in the Chinese population (7). A number of studies have revealed that bufalin induced biological activities such as inhibiting cell proliferation, and inducing cell differentiation and apoptosis 
in various cancer cells, including human hepatocellular carcinoma BEL-7402 cells (8), leukemia HL-60 (9) and U937 (10) cells, gastric cancer MGC803 cells (11), prostate cancer DU145 and PC3 cells (12), and glioma cancer cells (13). Bufalin also induced G0/G1 phase arrest and apoptosis in human bladder cancer T24 cells through mitochondria signaling pathways (14). In addition, bufalin inhibited human non-small lung cancer A549 cell proliferation via the vascular EGFR (VEGFR)1/VEGFR2/EGFR/tyrosine-protein kinase-protein kinase B/p44/p42/p38-nuclear factor- $\kappa \mathrm{B}$ signaling pathways (15). A previous study reported that the inhibition of the Janus kinase-signal transducer and activator of transcription 3 signaling pathway enhances bufalin-induced apoptosis in colon cancer SW620 cells (16).

Previous studies have demonstrated that bufalin induced cell death through cell cycle arrest and inducing apoptosis in many human cancer cell lines, there has yet to be a report investigating bufalin-induced cell death via the induction of apoptosis in human tongue cancer SCC-4 cells $(2,17)$. In addition, the molecular mechanism underlying bufalin-induced cell death in SCC-4 cells is unknown. In the present study, the SCC- 4 cell line was used as an in vitro tongue cancer model to investigate the effects of bufalin treatment. The present study reported that bufalin induced cell cycle arrest and induced cell apoptosis in SCC-4 cells via endoplasmic reticulum stress and caspase- and mitochondria-dependent pathways.

\section{Materials and methods}

Chemicals and reagents. Bufalin of $99 \%$ purity, 4',6-diamidino-2-phenylindole, dilactate (DAPI), dimethyl sulfoxide (DMSO), propidium iodide (PI) and Trypsin-EDTA were obtained from Sigma-Aldrich; Merck KGaA (Darmstadt, Germany). A stock solution of bufalin $(10 \mathrm{mM})$ was prepared in DMSO and further diluted in culture medium. DMSO was used as vehicle control in all experiments. Dulbecco's modified Eagle's medium (DMEM)/F12 (1:1) medium, fetal bovine serum (FBS), L-glutamine and penicillin-streptomycin were purchased from Gibco; Thermo Fisher Scientific, Inc. (Waltham, MA, USA). Primary antibodies and peroxidase-conjugated secondary antibodies were obtained from Santa Cruz Biotechnology, Inc. (Dallas, TX, USA). Fluo-3/AM, DiOC 6 , $\mathrm{H}_{2}$ DCF-DA and DAF-FM were obtained by Invitrogen (Carlsbad, CA, USA).

Cell culture. The SCC-4 human tongue cancer cell line was obtained from the Food Industry Research and Development Institute (Hsinchu, Taiwan) and cultured in DMEM/F12 (1:1) medium supplemented with $10 \% \mathrm{FBS}, 100 \mu \mathrm{g} / \mathrm{ml}$ streptomycin, 100 units/ml penicillin, and $2 \mathrm{mM}$ L-Glutamine at $37^{\circ} \mathrm{C}$ incubator with $5 \% \mathrm{CO}_{2}(18)$.

Cell morphology examinations, total viability and cell cycle assays. SCC-4 cells (1×105 cells/well) were cultured in 12-well plates with DMEM/F12 (1:1) medium for $24 \mathrm{~h}$. Cell were pretreated with or without inhibitor $[1 \mu \mathrm{M}$ cyclosporine $\mathrm{A}$, an inhibitor of $\Delta \Psi \mathrm{m}$ or $1 \mathrm{mM}$-acetyl cysteine (NAC), a general ROS scavenger; both from Sigma-Aldrich; Merck KGaA, Darmstadt, Germany] for $4 \mathrm{~h}$ at $37^{\circ} \mathrm{C}$, and then incubated with bufalin at a final concentration series of 100, 200, 300, 400 and $500 \mathrm{nM}$, or $0.5 \%$ DMSO only as a vehicle control for $48 \mathrm{~h}$ at $37^{\circ} \mathrm{C}$. Plated cells were examined and photographed under a contrast phase microscope at x200 magnification to analyze cell morphological changes. Cells were harvested and stained with PI $(4 \mathrm{mg} / \mathrm{ml})$ at room temperature, followed immediately by flow cytometry (FACSCalibur ${ }^{\mathrm{TM}}$; BD Biosciences, San Jose, CA, USA) to perform total viability assays or cells were analyzed for cell cycle distribution as previously described (19).

DAPI staining for chromatin condensation examination. SCC- 4 cells $\left(2 \times 10^{5}\right.$ cells/well) were cultured in 6-well plates and treated with bufalin $(100,200,300,400$ and $500 \mathrm{nM})$ or $0.5 \%$ DMSO only as a vehicle control for 24 and $48 \mathrm{~h}$ at $37^{\circ} \mathrm{C}$. Cells were fixed in $3 \%$ methanol in PBS at room temperature for $20 \mathrm{~min}$ and were then stained with DAPI solution $(2 \mu \mathrm{g} / \mathrm{ml})$ at $37^{\circ} \mathrm{C}$ for $30 \mathrm{~min}$. Cells were photographed using a fluorescence microscope as previously described (19). The ratio of nuclei condensation of cells to total cells was calculated; 150 cells/field in at least 3 fields from each well were counted. The analysis software to quantify the level of DNA damage was TriTek CometScore ${ }^{\mathrm{TM}}$ Freeware version 1.5 (TriTek Corp., Sumerduck, VA, USA).

DNA fragmentation assay by Comet assay and DNA gel electrophoresis. SCC-4 cells $\left(2 \times 10^{5}\right.$ cells/well) were cultured in 6-well plates for $24 \mathrm{~h}$ and incubated with bufalin (100, 300 and $500 \mathrm{nM}), 1.25 \mu \mathrm{M} \mathrm{H}_{2} \mathrm{O}_{2}$ or $0.5 \%$ DMSO only as a vehicle control for $48 \mathrm{~h}$ at $37^{\circ} \mathrm{C}$. All samples were collected for the Comet assay as described previously (20). SCC-4 cells $\left(1.5 \times 10^{6}\right.$ cells/dish) were cultured in $10-\mathrm{cm}$ dishes for $24 \mathrm{~h}$ and incubated with bufalin $(100,300$ and $500 \mathrm{nM})$ or $0.5 \%$ DMSO only as a vehicle control for $48 \mathrm{~h}$ at $37^{\circ} \mathrm{C}$, then cells were extracted using the Tissue and Cell Genomic DNA Purification kit (GMbiolab Co., Ltd., Taichung, Taiwan) as described previously (20). A total of $2 \mu \mathrm{g}$ DNA from each treatment group was loaded onto $0.5 \%$ agarose gels (at $100 \mathrm{~V}$ for $40 \mathrm{~min}$ ) in TBE buffer ( $89 \mathrm{mM}$ Triseboric acid and 2 mM EDTA, pH 8.0) for electrophoresis. Ethidium bromide was used for visualization and gels were photographed by fluorescence microscopy.

Measurements of reactive oxygen species (ROS), intracellular $\mathrm{Ca}^{2+}$, mitochondrial membrane potential $(\Delta \Psi \mathrm{m})$ and nitric oxide $(N O)$ production. The levels of $\operatorname{ROS}, \mathrm{Ca}^{2+}$ and $\Delta \Psi_{\mathrm{m}}$ in SCC-4 cells following exposure to bufalin were measured by a flow cytometric assay. Briefly, SCC -4 cells $\left(1 \times 10^{5}\right.$ cells/well $)$ in 12-well plates were treated with bufalin $(300 \mathrm{nM})$ or $0.5 \%$ DMSO only as a vehicle control for various time periods (0-9 h for ROS and NO measurements; 0-48 $\mathrm{h}$ for $\mathrm{Ca}^{2+}$ and $\Delta \Psi_{\mathrm{m}}$ measurements) at $37^{\circ} \mathrm{C}$. Cells were centrifuged at $453 \mathrm{xg}$ for $5 \mathrm{~min}$ at $25^{\circ} \mathrm{C}$ and resuspended with $500 \mu \mathrm{l}$ DCFH-DA $(10 \mu \mathrm{M})$ for $\operatorname{ROS}\left(\mathrm{H}_{2} \mathrm{O}_{2}\right)$ measurements, with $500 \mu \mathrm{l} \mathrm{DiOC}_{6}$ (4 $\mu \mathrm{mol} / \mathrm{l})$ for $\Delta \Psi_{\mathrm{m}}$ measurements, with $500 \mu \mathrm{l}$ Fluo-3/AM $(2.5 \mu \mathrm{g} / \mathrm{ml})$ for intracellular $\mathrm{Ca}^{2+}$ concentration measurements and with $500 \mu \mathrm{l}$ DAF-FM $(10 \mu \mathrm{M})$ to measure NO production. All samples were maintained in the dark for $30 \mathrm{~min}$ at $37^{\circ} \mathrm{C}$ and then analyzed by flow cytometry as described previously (21).

Western blot analysis. Western blotting was performed to detect the levels of apoptotic proteins. SCC-4 cells 
( $5 \times 10^{6}$ cells/dish) were cultured in a $10 \mathrm{~cm}$ dish for $24 \mathrm{~h}$ and were then incubated with $0.5 \%$ DMSO only as a vehicle control or $300 \mathrm{nM}$ bufalin for $0,12,24,36$ and $48 \mathrm{~h}$ at $37^{\circ} \mathrm{C}$. The protein was lysed by PRO-PREP Protein Extraction Solution (iNtRON Biotechnology, Sungnam, Korea), and total protein was measured using a Bio-Rad protein assay kit (Bio-Rad Laboratories, Inc., Hercules, CA, USA) as described previously (21). Proteins $(20 \mu \mathrm{g})$ were separated by electrophoresis $12 \%(\mathrm{v} / \mathrm{v})$ SDS-PAGE and then transferred onto polyvinylidene difluoride membranes (EMD Millipore, Billerica, MA, USA). Membranes were blocked for $1 \mathrm{~h}$ at room temperature with 5\% non-fat milk in PBST (0.1\% Tween-20 in 1X PBS), then hybridized with the following primary antibodies at $4^{\circ} \mathrm{C}$ overnight. The primary antibodies supplied by Santa Cruz Biotechnology, Inc. (Dallas, TX, USA) were used at a 1:1,000 dilution; endonuclease $\mathrm{G}$ (Endo G; sc-365359), apoptosis-inducing factor (AIF; sc-13116), cytochrome (Cyt) $c$ (sc-13560), X-box binding protein (XBP)-1 (sc-7160), DNA damage inducible transcript 3 (GADD153; sc-7351), inositol-requiring enzyme (IRE)-1 $\alpha$ (sc-25563), activating transcription factor (ATF)-6 $\alpha$ (sc-58323), ATF-6 $\beta$ (sc-30596), glucose-regulated protein, $78 \mathrm{kDa}$ (GRP78; sc-13968), calpain-1 (sc-58323) and tumor necrosis factor (TNF)-related apoptosis-inducing ligand (TRAIL; sc-80393). The primary antibody supplied by EMD Millipore was used at a 1:500 dilution for BH3 interacting-domain death agonist (Bid; AB1730). The primary antibodies supplied by Cell Signaling Technology, Inc. (Danvers, MA, USA) were used at a 1:1,000 dilution for B-cell lymphoma 2 (Bcl-2; 2870), Bcl-2-associated X protein (Bax; 2772), death receptor (DR) 5 (8074), DR4 (42533), PARP (9532), caspase-3 (9669) and caspase-9 (9508). The primary antibody supplied by Sigma-Aldrich (Merck KGaA) was used at a 1:10,000 dilution for $\beta$-actin (A5316). This was followed by incubation with the secondary antibody at room temperature $\left(25^{\circ} \mathrm{C}\right)$ for $1 \mathrm{~h}$. The secondary antibodies supplied by GeneTex (Irvine, CA, USA) were used at a 1:10,000 dilution for horseradish peroxidase (HRP)-conjugated goat anti-rabbit IgG (GTX213110), HRP-conjugated donkey anti-goat IgG (GTX26885) and HRP-conjugated rabbit anti-mouse IgG (GTX213112). Protein bands were visualized by chemiluminescence signals, which were enhanced using electrochemiluminescence detection (Amersham ECL ${ }^{\mathrm{TM}}$; GE Healthcare, Chicago, IL, USA) $(21,22)$. ImageJ version $1.49 \mathrm{o}$ software (National Institutes of Health, Bethesda, MD, USA) was used to quantify changes in protein expression by densitometry analysis and using $\beta$-actin as the loading control.

Statistical analysis. All values are presented as the mean \pm standard deviation of three independent experiments. Differences between groups were analyzed by one-way analysis of variance and Dunnett or Tukey test for multiple comparisons (SigmaPlot for Windows version 12.0; Systat Software, Inc., San Jose, CA). P $<0.05$ was considered to indicate a statistically significant difference.

\section{Results}

Bufalin induces cell morphological changes, decreases total viability and induces $G 2 / M$ phase arrest in SCC-4 cells. Following exposure to various concentrations of bufalin
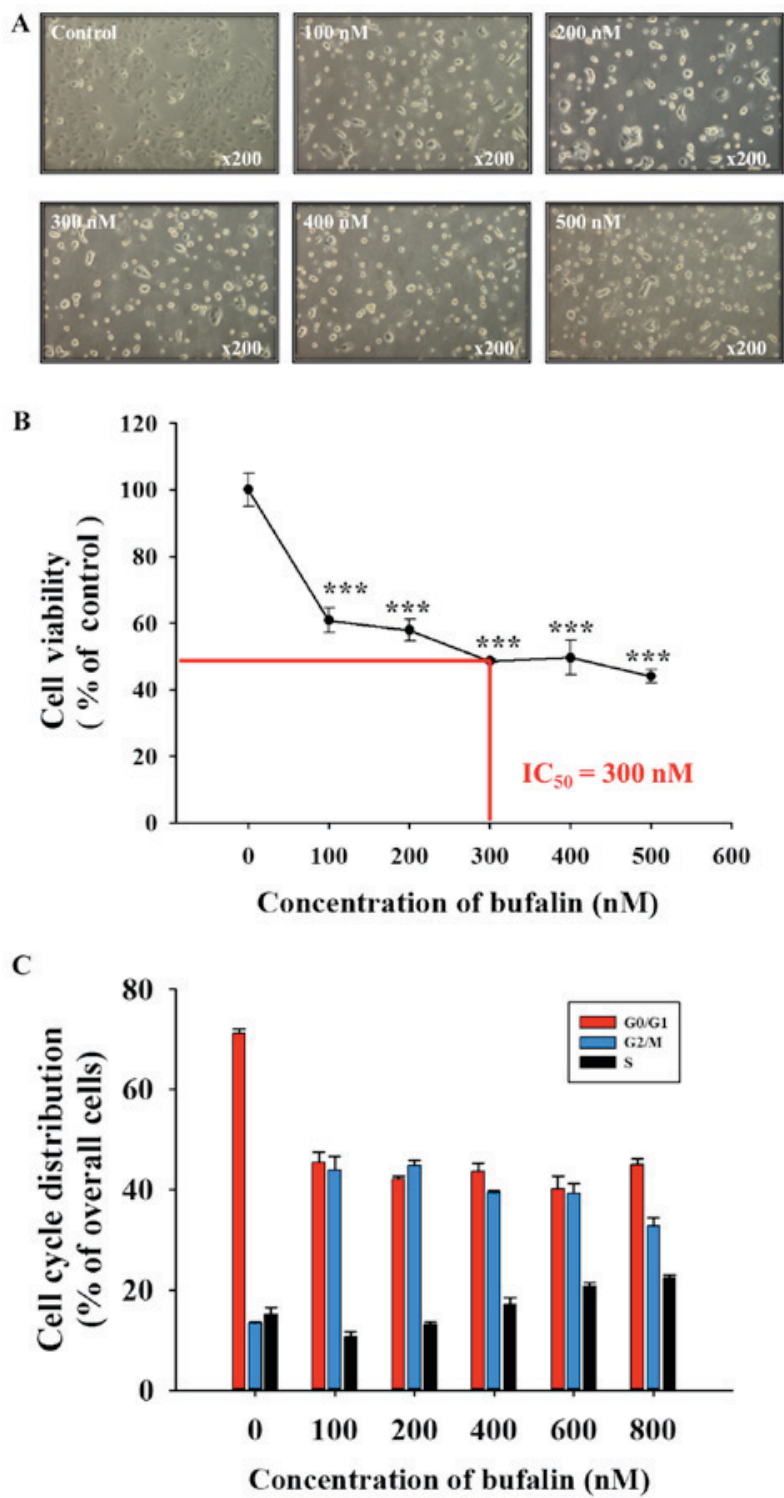

Figure 1. Bufalin induced cell morphological changes, decreased cell viability and induced G2/M phase arrest in SCC-4 cells. (A) Cells were treated with $0,100,200,300,400$ and $500 \mathrm{nM}$ of bufalin for $48 \mathrm{~h}$ and subsequently examined and photographed for cell morphological changes by phase contrast microscopy. Magnification, x200. Cells were harvested to analyze the (B) number of viable cells and (C) the cell cycle distribution by flow cytometry. The results are presented as the mean \pm standard deviation $(\mathrm{n}=3) .{ }^{* * *} \mathrm{P}<0.001$ vs. $0 \mathrm{nM}$ bufalin (control). $\mathrm{IC}_{50}$, half-maximal inhibitory concentration.

for $48 \mathrm{~h}, \mathrm{SCC}-4$ cells were examined to determine any cytotoxic effects (Fig. 1). Bufalin induced cell morphological changes (cell shrinkage, cytoplasmic and nuclear condensation or pyknosis) and reduced the total cell viability in a dose-dependent manner; a half-maximal inhibitory concentration $\left(\mathrm{IC}_{50}\right.$ ) of $300 \mathrm{nM}$ was observed at $48 \mathrm{~h}$ (Fig. 1A and $\mathrm{B})$. In addition, bufalin induced $\mathrm{G} 2 / \mathrm{M}$ phase arrest in SCC-4 cells (Fig. 1C). Therefore, the findings of the present study indicated that bufalin may induce cytotoxic effects on SCC-4 cells via cell morphological changes and by decreasing the number of viable SCC-4 cells in vitro.

Bufalin induces chromatin condensation in SCC-4 cells. Following treatment with bufalin $(0,100,200,300,400$ 

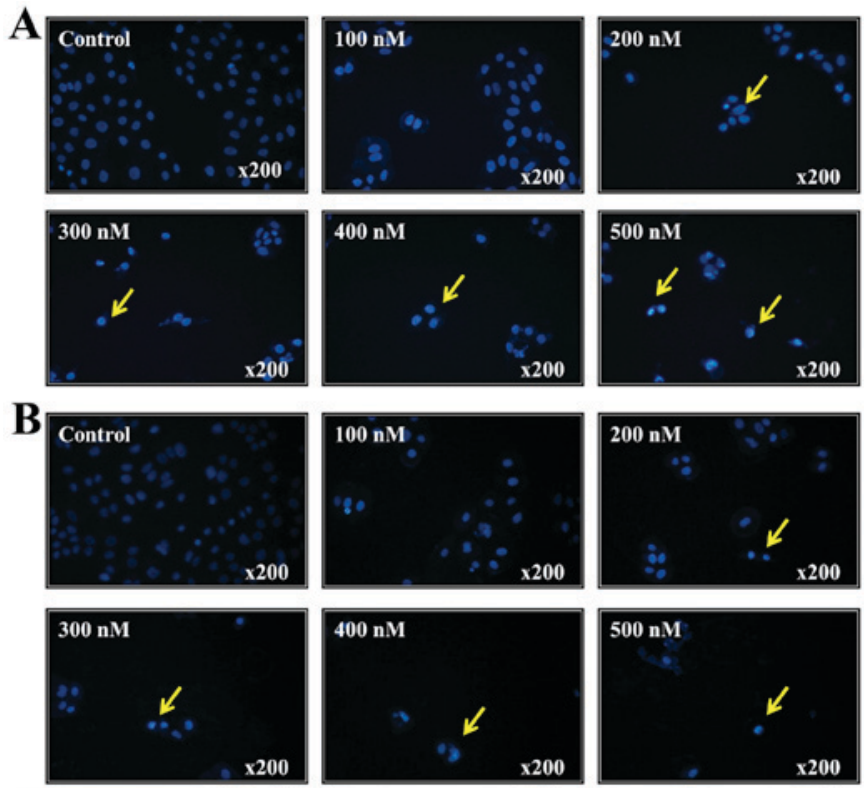

$\mathrm{C}$

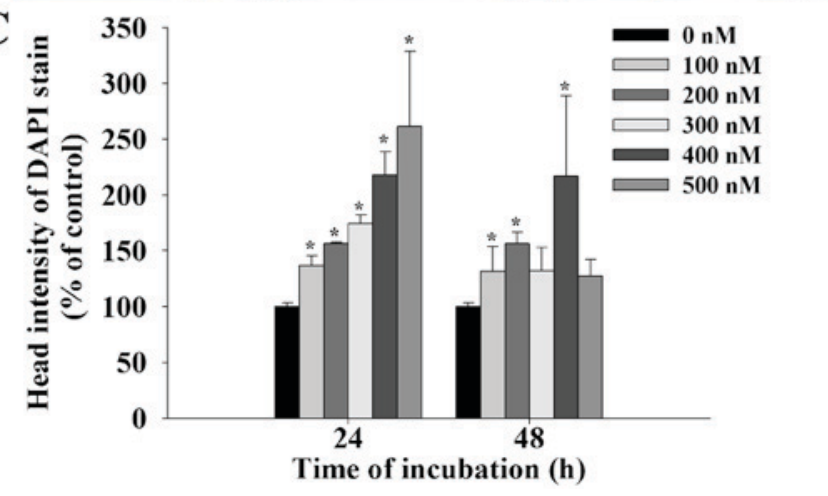

Figure 2. Bufalin induced chromatin condensation in SCC-4 cells. Cells were treated with $0,100,200,300,400$ and $500 \mathrm{nM}$ of bufalin for (A) 24 and (B) $48 \mathrm{~h}$ and then stained with DAPI. Yellow arrows indicate areas of positive DAPI staining. (C) The intensity of DAPI staining was calculated to determine the level of chromatin condensation. The results are presented as the mean \pm standard deviation $(\mathrm{n}=3)$. ${ }^{*} \mathrm{P}<0.05$ vs. $0 \mathrm{nM}$ bufalin (control). DAPI, 4',6-diamidino-2-phenylindole, dilactate.

and $500 \mathrm{nM}$ ) for 24 and $48 \mathrm{~h}$, SCC-4 cells were stained with DAPI and photographed using fluorescence microscopy; the results are presented in Fig. 2. Treatment with bufalin at 100-500 $\mathrm{nM}$ for 24 and $48 \mathrm{~h}$, induced brighter DAPI fluorescence in SCC-4 cells when compared with control cells (Fig. 2A and B). Brighter fluorescence indicates nicked DNA and chromatin condensation, which were observed in SSC-4 cells in a dose-dependent manner (Fig. 2C). These findings indicate that bufalin may induce early and late apoptosis in SCC-4 cells, characterized by the presence of irregular and fragmented nuclei, and shrunken cells.

Bufalin induces DNA fragmentation and DNA damage in $S C C$ - 4 cells. It has been previously revealed that DNA fragmentation (DNA ladder) is one of the hallmarks of apoptotic cell death (23). Following SCC-4 cell treatment with bufalin $(0$, 100,300 and $500 \mathrm{nM}$ ) for $48 \mathrm{~h}$, total DNA was isolated from each treatment group and run on DNA agarose gel electrophoresis (Fig. 3A). Bufalin induced a typical DNA ladder for all 3 examined doses in SCC- 4 cells. In addition, the results of the Comet assay indicated that bufalin-induced DNA damage
$\mathbf{A}$
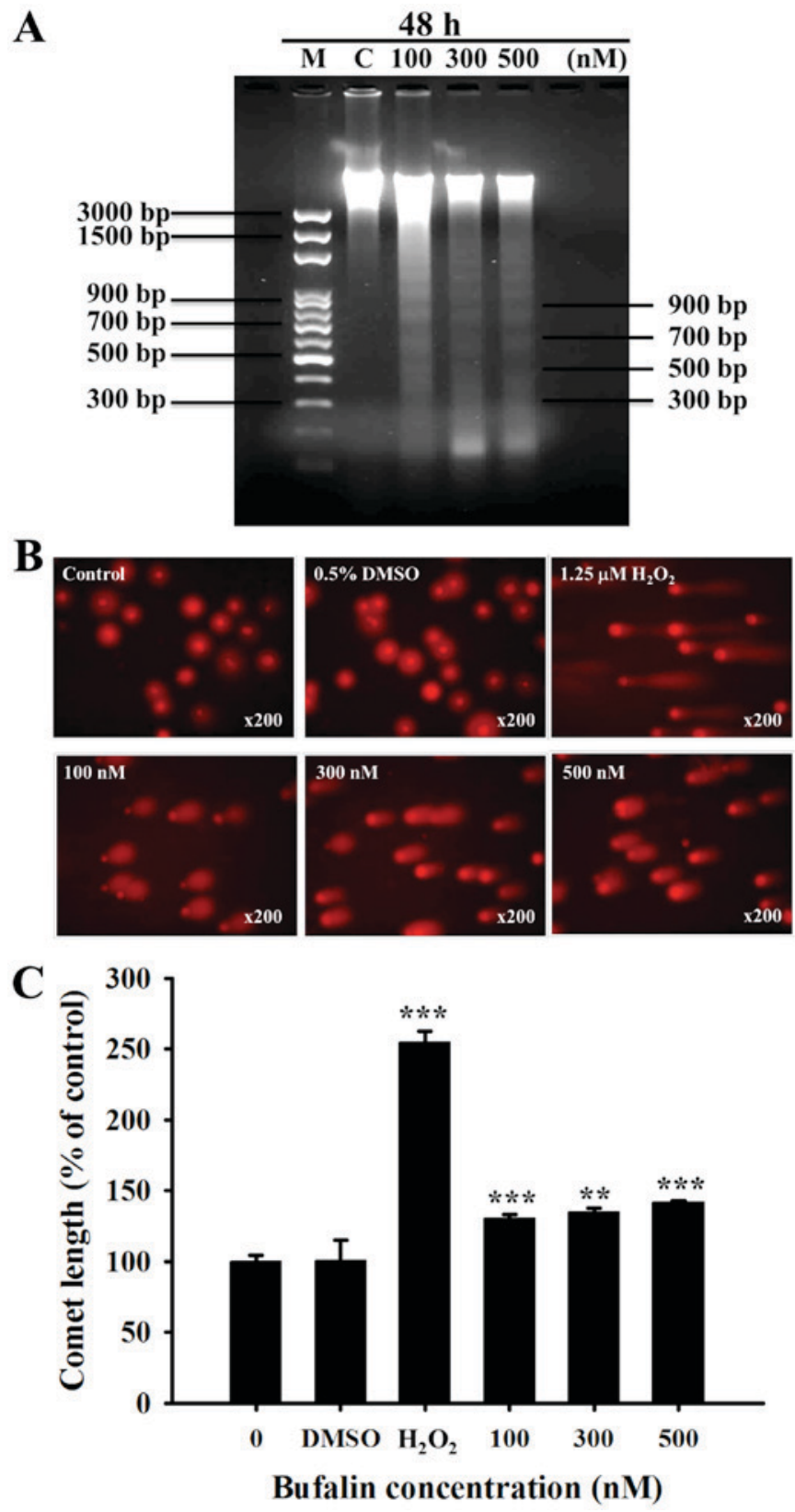

Figure 3. Bufalin induced DNA fragmentation and damage in SCC-4 cells. Cells were treated with $0.5 \%$ DMSO, $1.25 \mu \mathrm{M} \mathrm{H}_{2} \mathrm{O}_{2}$, or $0,100,300$ and $500 \mu \mathrm{M}$ of bufalin for $48 \mathrm{~h}$, and then DNA was isolated to analyze (A) DNA fragmentation (DNA ladder) by DNA gel electrophoresis or (B) to analyze DNA damage by a Comet assay and (C) quantitating the length of comet tails. Magnification, $\mathrm{x} 200$. The results are presented as the mean \pm standard deviation $(\mathrm{n}=3) .{ }^{* *} \mathrm{P}<0.01$ and ${ }^{* * *} \mathrm{P}<0.001$ vs. $0 \mathrm{nM}$ bufalin (control). $\mathrm{M}$, marker; C, control (0 nM bufalin); DMSO, dimethyl sulfoxide.

based on the production of Comet tails (Fig. 3B); these effects were observed in a dose-dependent manner (Fig. 3C).

Bufalin induces the production of $\mathrm{ROS}$ and $\mathrm{Ca}^{2+}$, and decreases the levels of $\triangle \Psi m$ and $N O$ in SCC-4 cells. In order to further investigate whether bufalin-induced cell apoptosis is involved in the production of $\mathrm{ROS}, \mathrm{Ca}^{2+}$ and $\mathrm{NO}$, or the dysfunction of the $\Delta \Psi \mathrm{m}, \mathrm{SCC}-4$ cells were treated with $300 \mathrm{nM}$ bufalin for various time periods. All samples were collected and analyzed by a flow cytometric assay (Fig. 4). The results revealed that bufalin decreased the production 


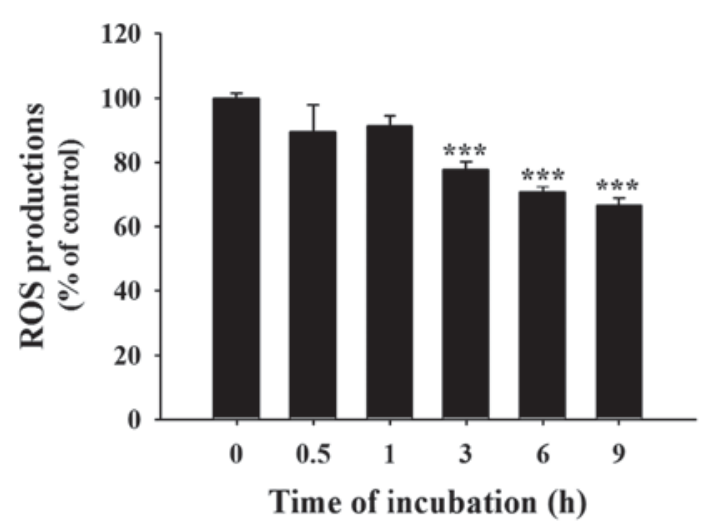

C

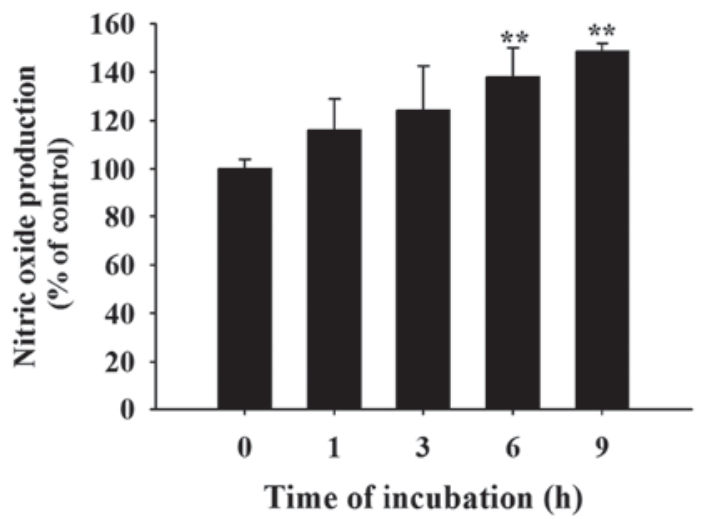

$\mathbf{E}$

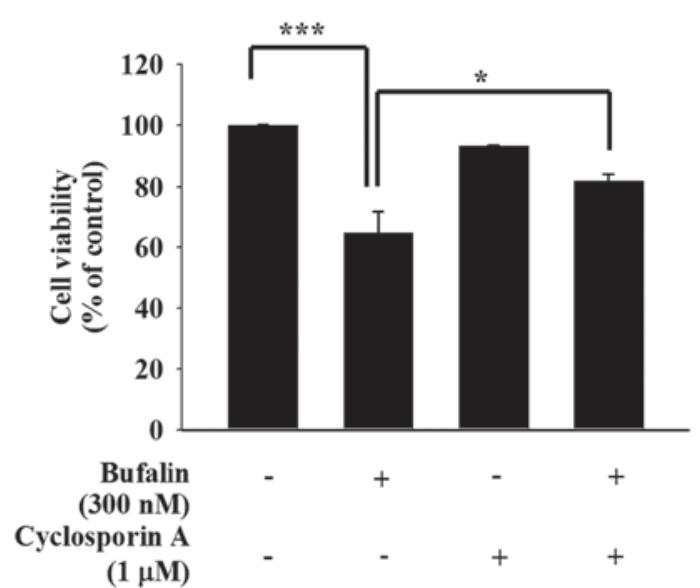

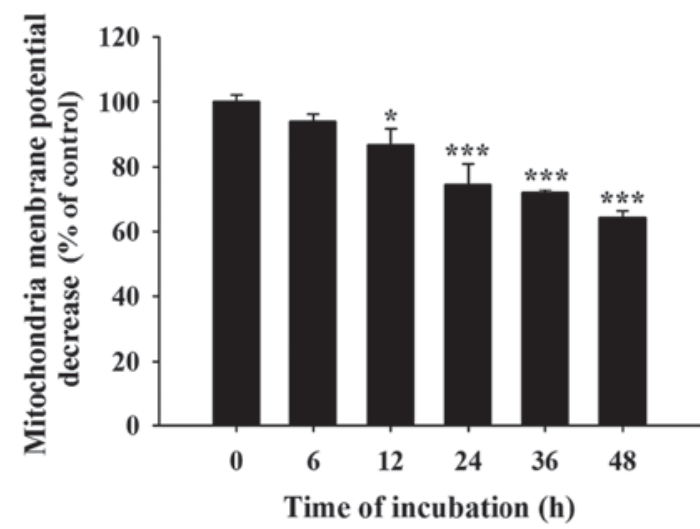

D

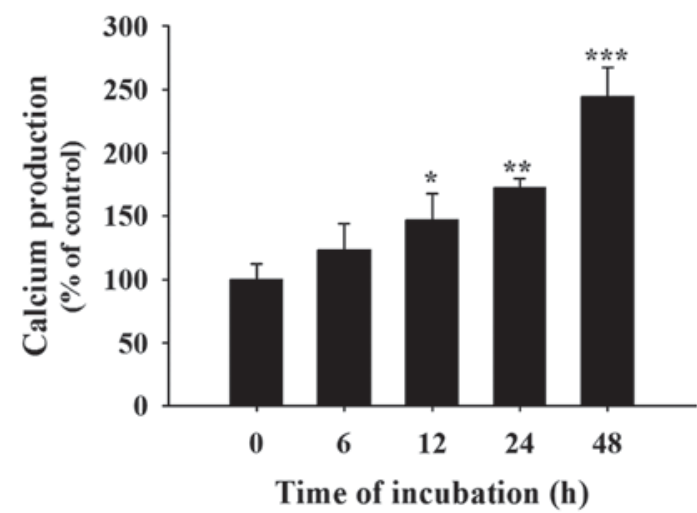

Figure 4. Bufalin affected the production of ROS, $\mathrm{NO}$ and $\mathrm{Ca}^{2+}$ and the $\triangle \Psi \mathrm{m}$ in SCC-4 cells. Cells were isolated and resuspended in different reagents to analyze the levels of (A) ROS (in $500 \mu 1$ of $10 \mu \mathrm{M}$ DCFH-DA), (B) $\Delta \Psi_{\mathrm{m}}$ (in $500 \mu \mathrm{l}$ of $4 \mu \mathrm{mol} / 1 \mathrm{DiOC}_{6}$ ), (C) NO (in $500 \mu 1$ of $10 \mu \mathrm{M}$ DAF-FM) and (D) intracellular Ca ${ }^{2+}$ concentrations $\left(500 \mu \mathrm{l}\right.$ of $2.5 \mu \mathrm{g} / \mathrm{ml}$ Fluo-3/AM), and these results are presented as the mean \pm standard deviation $(\mathrm{n}=3)$. ${ }^{*} \mathrm{P}<0.05 ;{ }^{* *} \mathrm{P}<0.01 ;{ }^{* * *} \mathrm{P}<0.001 \mathrm{vs} .0 \mathrm{nM}$ bufalin (Dunnett multiple comparisons test). (E) Cells were also pretreated with $1 \mu \mathrm{M}$ cyclosporine A, then incubated with $300 \mathrm{nM}$ bufalin for $48 \mathrm{~h}$ to determine the percentage of viable cells, and the result is presented as the mean \pm standard deviation $(\mathrm{n}=3) .{ }^{*} \mathrm{P}<0.05 ;{ }^{* * * *} \mathrm{P}<0.001$, denotes statistically significant difference (Tukey multiple comparisons test). ROS, reactive oxygen species; NO, nitric oxide; $\Delta \Psi \mathrm{m}$, mitochondrial membrane potential.

of ROS following 1-9 h of treatment (Fig. 4A) and the $\Delta \Psi \mathrm{m}$ following 6-48 h of treatment (Fig. 4B). However, 6-9 h of bufalin treatment increased NO production (Fig. 4C) and increased $\mathrm{Ca}^{2+}$ production following $12-48 \mathrm{~h}$ of treatment (Fig. 4D). Cells were also pretreated with $1 \mu \mathrm{M}$ cyclosporine A, an inhibitor of $\Delta \Psi \mathrm{m}$, for $4 \mathrm{~h}$ at $37^{\circ} \mathrm{C}$ and then co-treated with or without $300 \mathrm{nM}$ bufalin to analyze cell viability. The results demonstrated that pretreatment with cyclosporine A increased cell viability when compared with bufalin only treatment (Fig. 4E). These findings indicate that ROS, NO,
$\mathrm{Ca}^{2+}$ and $\Delta \Psi \mathrm{m}$ may be involved in bufalin-induced apoptotic cell death in SCC-4 cells in vitro.

Bufalin alters apoptosis-associated protein expression in SCC-4 cells. The present study also investigated whether bufalin-induced cell apoptosis alters the expression of apoptosis-associated proteins in SCC-4 cells. Cells were treated with bufalin (300 nM) for $0,12,24,36$ and $48 \mathrm{~h}$, then proteins were measured and quantitated by western blotting (Fig. 5). The results demonstrated that following $48 \mathrm{~h}$ 
A
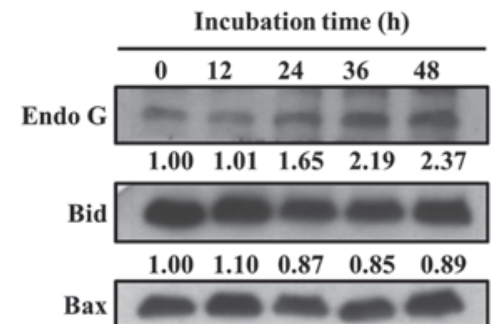

$\begin{array}{lllll}1.00 & 1.28 & 1.05 & 1.22 & 1.44\end{array}$

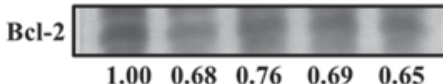

PARP

$\begin{array}{lllll}1.00 & 0.68 & 0.76 & 0.69 & 0.65\end{array}$

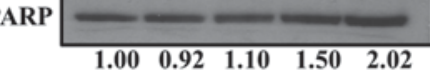

AIF

$\begin{array}{lllll}1.00 & 0.92 & 1.10 & 1.50 & 2.02\end{array}$

$\begin{array}{lllll}1.00 & 0.79 & 1.19 & 1.21 & 1.16\end{array}$

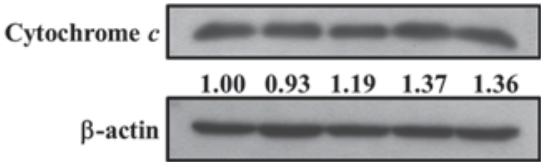

B

TR

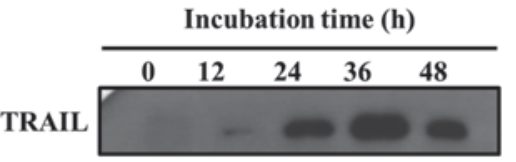

$\begin{array}{llllll}1.00 & 1.25 & 3.48 & 5.49 & 3.24\end{array}$

DR5
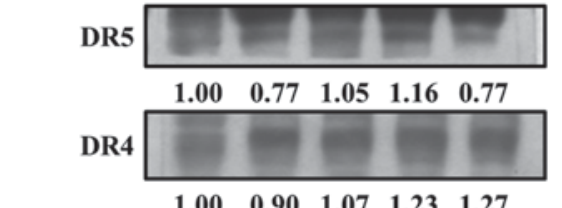

Caspase-3

$\begin{array}{lllll}1.00 & 0.90 & 1.07 & 1.23 & 1.27\end{array}$

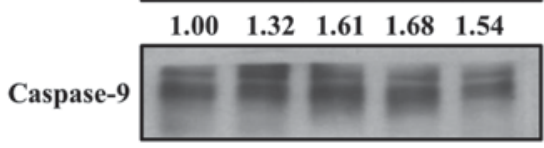

$\begin{array}{lllll}1.00 & 1.06 & 1.22 & 1.10 & 0.79\end{array}$

$\beta$-actin

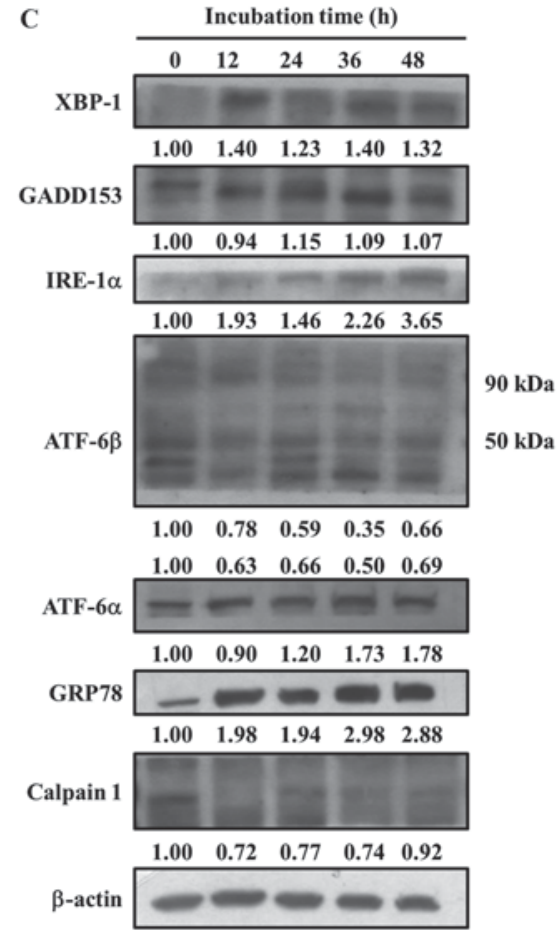

Figure 5. Bufalin affects apoptosis-associated protein expression in SCC-4 cells. Cells were treated with $300 \mathrm{nM}$ of bufalin for $0,12,24,36$ and $48 \mathrm{~h}$ and then total proteins were quantified by western blotting. The expression of the following apoptosis-associated proteins was analyzed and normalized to $\beta$-actin: (A) Endo G, Bid, Bax, Bcl-2, PARP, AIF and cytochrome $c$; (B) TRAIL, DR5, DR4, caspase-3 and -9; (C) XBP-1, GADD153, IRE-1 $\alpha$, ATF-6 $\beta$, ATF-6 $\alpha$, GRP78 and Calpain 1. Endo G, endonuclease G; Bid, BH3 interacting-domain death agonist; Bcl-2, B-cell lymphoma 2; Bax, Bcl-2-associated X protein; PARP, poly(ADP-ribose) polymerase; AIF, apoptosis-inducing factor; TRAIL, tumor necrosis factor-related apoptosis-inducing ligand; DR, death receptor; XBP-1, X-box binding protein 1; GADD153, DNA damage inducible transcript 3; IRE-1 $\alpha$, inositol-requiring enzyme 1 $\alpha$; ATF, activating transcription factor; GRP78, heat shock $70 \mathrm{kDa}$ protein 5 (glucose-regulated protein, $78 \mathrm{kDa}$ ).

of incubation, bufalin markedly increased the expression of Endo G, Bcl-2, Bax, poly(ADP-ribose) polymerase, AIF, Cyt $c$ (Fig. 5A), TRAIL, DR4, caspase-3 (Fig. 5B), XBP1, GADD153, IRE-1 $\alpha$, ATF-6 $\alpha$ and GRP78 (Fig. 5C). Bufalin treatment for $36 \mathrm{~h}$ increased the expression of DR5 and caspase-9 (Fig. 5B); however, following $48 \mathrm{~h}$ their expression decreased when compared with $0 \mathrm{~h}$ of treatment. In addition, bufalin treatment markedly reduced the expression of $\mathrm{Bcl}-2$, Bid (Fig. 5A), calpain 1 and ATF-6 $\beta$ (Fig. 5C). These results indicated that bufalin may induce apoptosis in SCC-4 cells via mitochondria-dependent signaling pathways.

\section{Discussion}

Previous studies have demonstrated that bufalin induces cell death via cell cycle arrest and inducing apoptosis in many human cancer cells $(2,24,25)$; however, currently there is a lack of information available on bufalin-induced apoptosis in human tongue cancer SCC-4 cells in vitro. Thus, the present study investigated the cytotoxic effects of bufalin on human tongue cancer SCC-4 cells. The results indicated that: i) Bufalin induced cell morphological changes and reduced the total number of viable cells (Fig. 1); ii) bufalin induced chromatin condensation (Fig. 2), DNA fragmentation (apoptotic cell death) and DNA damage (Fig. 3); iii) bufalin increased $\mathrm{NO}$ and $\mathrm{Ca}^{2+}$ levels; however, treatment decreased the levels of ROS and $\Delta \Psi \mathrm{m}$ (Fig. 4); and iv) bufalin increased the expression of pro-apoptotic proteins, including Bax, Endo G and AIF, and decreased the expression anti-apoptotic proteins such as Bcl-2 and calpain 1 (Fig. 5).

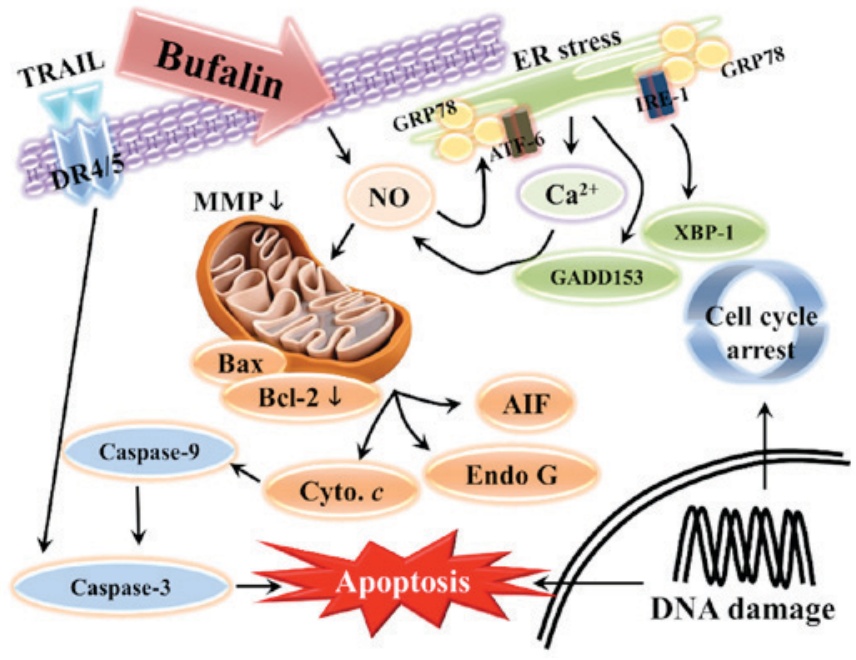

Figure 6. Schematic of the potential signaling pathways used by bufalin to induce apoptosis in SCC-4 human tongue cancer cells. Endo G, endonuclease G; Bcl-2, B-cell lymphoma 2; Bax, Bcl-2-associated X protein; AIF, apoptosis-inducing factor; TRAIL, tumor necrosis factor-related apoptosis-inducing ligand; DR, death receptor; XBP-1, X-box binding protein 1; GADD153, DNA damage inducible transcript 3; IRE-1 $\alpha$, inositol-requiring enzyme $1 \alpha$; ATF, activating transcription factor; GRP78, heat shock $70 \mathrm{kDa}$ protein 5 (glucose-regulated protein, $78 \mathrm{kDa}$ ); NO, nitric oxide; ER, endoplasmic reticulum; MMP, mitochondrial membrane potential.

The present study indicated that bufalin reduced the total percentage of viable cells in a dose-dependent manner, which is similar to findings reported previously in other cell 
lines (26-28); the results of the present study also identified an $\mathrm{IC}_{50}$ of $300 \mathrm{nM}$ following $48 \mathrm{~h}$ treatment in SCC-4 cells. In addition, bufalin induced $\mathrm{G} 2 / \mathrm{M}$ phase arrest in SCC-4 cells, which is also in agreement with previous reports $(11,29-31)$. It has been previously established that anticancer drugs, such as paclitaxel have been used for treating patients with cancer, also known to induce G2/M phase arrest (32). Apoptosis has been demonstrated to be one of the potential mechanisms of anticancer activity and it is also a fundamental process in the development of various cell types $(33,34)$. Therefore, the present study further investigated the induction of apoptosis in SCC-4 cells in vitro. DAPI staining and DNA gel electrophoresis were performed to confirm that bufalin induced cell apoptosis in SCC-4 cells. The results demonstrated that bufalin significantly induced cell apoptosis in SCC-4 cells in dose-dependent manner.

Apoptosis pathways can be divided into two types: The death receptor (extrinsic) pathway and the mitochondrial (intrinsic) pathway (35). The death receptor pathway may function via receptors including the Fas cell surface death receptor, DR5 and DR4, which then activate caspase-8, followed by caspase- 9 and -3 in order to induce apoptosis or it may trigger mitochondrial dysfunction to induce the intrinsic cell apoptotic pathway $(36,37)$. The western blotting results revealed that bufalin promoted the expression of TRAIL and DR4 following $48 \mathrm{~h}$, and DR5 following $36 \mathrm{~h}$ of treatment, indicating that bufalin may have induced cell apoptosis via the death (extrinsic) receptor pathway. DR4 and DR5 proteins are involved in apoptosis and are the membrane receptors for TRAIL (38). In addition, other membrane receptors for TRAIL are also involved in inducing apoptosis (39). Bufalin was also observed to increase the protein expression of caspase-3 following $48 \mathrm{~h}$, and caspase- 9 following $36 \mathrm{~h}$, which supports the involvement of both pathways.

Flow cytometric analysis indicated that bufalin increased the production of $\mathrm{Ca}^{2+}$ and $\mathrm{NO}$, and decreased the levels of $\Delta \Psi \mathrm{m}$ and ROS in SCC-4 cells in a time-dependent manner. SCC-4 cells were also pretreated with $1 \mathrm{mM} \mathrm{NAC}$ for $4 \mathrm{~h}$ at $37^{\circ} \mathrm{C}$ and then co-treated with or without bufalin. As expected, the general ROS scavenger NAC did not significantly decrease bufalin-induced ROS generation and did not increase the total number of viable cells (data not shown). ROS have an important role in cancer cell death; under starvation or stress conditions, the levels of ROS are increased for the induction of autophagy (40). These findings indicate that bufalin did not induce cell apoptosis via the ROS signaling pathway. $\mathrm{Ca}^{2+}$ uptake into the mitochondrial matrix has been demonstrated to be critical for cellular function (41). The present study revealed that bufalin promoted $\mathrm{Ca}^{2+}$ release. In addition, bufalin significantly reduced the $\Delta \Psi \mathrm{m}$, and pretreatment with cyclosporine $\mathrm{A}$, followed by bufalin treatment increased the total number of viable SCC-4 cells when compared with bufalin treatment only. Anticancer drugs may induce cell apoptosis through the dysfunction of mitochondria or by decreasing $\Delta \Psi \mathrm{m}(42,43)$, and mitochondria are involved in the stimulation of apoptosis in the intrinsic signaling pathway (44). Thus, the results of the present study suggest that bufalin may induce cell apoptosis via a mitochondria-dependent signaling pathway in SCC-4 cells. Western blot analysis revealed that bufalin increased the expression of the pro-apoptotic protein
Bax and reduced the expression of the anti-apoptotic protein Bcl-2. Previous studies determined that the ratio of $\mathrm{Bax} / \mathrm{Bcl}-2$ affects the $\Delta \Psi \mathrm{m}$, and in turn the initiation of apoptosis $(45,46)$. Mitochondrial control of apoptosis is thought to primarily involve the $\Delta \Psi \mathrm{m}$ and membrane permeability (47). Thus, if the levels of $\Delta \Psi \mathrm{m}$ are reduced, cytochrome $c$, AIF or Endo $\mathrm{G}$ may release from the mitochondria, triggering apoptosis.

In conclusion, to the best of our knowledge, the present study demonstrated for the first time that bufalin treatment inhibits the progression of SCC-4 human tongue cancer cells in vitro. Bufalin induced cell morphological changes, reduced the number of viable cells, and induced $\mathrm{G} 2 / \mathrm{M}$ phase arrest and apoptosis. Bufalin may have triggered cell apoptosis via a mitochondria-dependent signaling pathway in SCC-4 cells, which is summarized in Fig. 6. Apoptosis may also have been induced via the extrinsic pathway, which involves DR4, DR5, TRAIL and various caspases, or via intrinsic pathways that lead to the release of AIF and Endo G in order to induce apoptosis.

\section{Acknowledgements}

The present study was supported by China Medical University, Taichung, Taiwan, R.O.C. (grant no. CMU101-ASIA-09).

\section{References}

1. Khalili J: Oral cancer: Risk factors, prevention and diagnostic. Exp Oncol 30: 259-264, 2008.

2. Lee CH, Shih YL, Lee MH, Au MK, Chen YL, Lu HF and Chung JG: Bufalin induces apoptosis of human osteosarcoma U-2 os cells through endoplasmic reticulum stress, caspase- and mitochondria-dependent signaling pathways. Molecules 22: E437, 2017.

3. Gomez DR, Zhung JE, Gomez J, Chan K, Wu AJ, Wolden SL, PfisterDG, Shaha A, Shah JP,Kraus DH, et al: Intensity-modulated radiotherapy in postoperative treatment of oral cavity cancers. Int J Radiat Oncol Biol Phys 73: 1096-1103, 2009.

4. Major AG, Pitty LP and Farah CS: Cancer stem cell markers in head and neck squamous cell carcinoma. Stem Cells Int 2013: 319489, 2013.

5. Urban D, Corry J and Rischin D: What is the best treatment for patients with human papillomavirus-positive and -negative oropharyngeal cancer?. Cancer 120: 1462-1470, 2014.

6. Krenn L and Kopp B: Bufadienolides from animal and plant sources. Phytochemistry 48: 1-29, 1998.

7. Meng Z, Yang P, Shen Y, Bei W, Zhang Y, Ge Y, Newman RA, Cohen L, Liu L, Thornton B, et al: Pilot study of huachansu in patients with hepatocellular carcinoma, nonsmall-cell lung cancer, or pancreatic cancer. Cancer 115: 5309-5318, 2009.

8. Han KQ, Huang G, Gu W, Su YH, Huang XQ and Ling CQ: Anti-tumor activities and apoptosis-regulated mechanisms of bufalin on the orthotopic transplantation tumor model of human hepatocellular carcinoma in nude mice. World J Gastroenterol 13: 3374-3379, 2007

9. Hashimoto S, Jing Y, Kawazoe N, Masuda Y, Nakajo S, Yoshida T, Kuroiwa Y and Nakaya K: Bufalin reduces the level of topoisomerase II in human leukemia cells and affects the cytotoxicity of anticancer drugs. Leuk Res 21: 875-883, 1997.

10. Watabe M, Ito K, Masuda Y, Nakajo S and Nakaya K: Activation of AP-1 is required for bufalin-induced apoptosis in human leukemia U937 cells. Oncogene 16: 779-787, 1998.

11. Li D, Qu X, Hou K, Zhang Y, Dong Q, Teng Y, Zhang J and Liu Y: PI3 K/Akt is involved in bufalin-induced apoptosis in gastric cancer cells. Anticancer Drugs 20: 59-64, 2009.

12. Yu CH, Kan SF, Pu HF, Jea Chien E and Wang PS: Apoptotic signaling in bufalin- and cinobufagin-treated androgen-dependent and -independent human prostate cancer cells. Cancer Sci 99: 2467-2476, 2008

13. Shen S, Zhang Y, Wang Z, Liu R and Gong X: Bufalin induces the interplay between apoptosis and autophagy in glioma cells through endoplasmic reticulum stress. Int J Biol Sci 10: 212-224, 2014. 
14. Huang WW, Yang JS, Pai SJ, Wu PP, Chang SJ, Chueh FS, Fan MJ, Chiou SM, Kuo HM, Yeh CC, et al: Bufalin induces G0/G1 phase arrest through inhibiting the levels of cyclin D, cyclin E, CDK2 and CDK4 and triggers apoptosis via mitochondrial signaling pathway in T24 human bladder cancer cells. Mutat Res 732: 26-33, 2012.

15. Jiang Y, Zhang Y, Luan J, Duan H, Zhang F, Yagasaki K and Zhang G: Effects of bufalin on the proliferation of human lung cancer cells and its molecular mechanisms of action. Cytotechnology 62: 573-583, 2010.

16. Zhu Z, Li E, Liu Y, Gao Y, Sun H, Ma G, Wang Z, Liu X, Wang Q, Qu X, et al: Inhibition of Jak-STAT3 pathway enhances bufalin-induced apoptosis in colon cancer SW620 cells. World J Surg Oncol 10: 228, 2012.

17. Wu SH, Wu TY, Hsiao YT, Lin JH, Hsu SC, Hsia TC, Yang ST, Hsu WH and Chung JG: Bufalin induces cell death in human lung cancer cells through disruption of DNA damage response pathways. Am J Chin Med. 42: 729-742. 2014.

18. Chang Y-M, Velmurugan BK, Kuo W-W, Chen Y-S, Ho T-J, Tsai C-T, Ye C-X, Tsai C-H, Tsai F-J and Huang C-Y: Inhibitory effect of alpinate Oxyphyllae fructus extracts on Ang II-induced cardiac pathological remodeling-related pathways in $\mathrm{H} 9 \mathrm{c} 2$ cardiomyoblast cells. Biomedicine 3: 148-152, 2013.

19. Yu FS, Huang AC, Yang JS, Yu CS, Lu CC, Chiang JH, Chiu CF and Chung JG: Safrole induces cell death in human tongue squamous cancer SCC-4 cells through mitochondria-dependent caspase activation cascade apoptotic signaling pathways. Environ Toxicol 27: 433-444, 2012.

20. Chueh FS, Chen YL, Hsu SC, Yang JS, Hsueh SC, Ji BC, Lu HF and Chung JG: Triptolide induced DNA damage in A375.S2 human malignant melanoma cells is mediated via reduction of DNA repair genes. Oncol Rep 29: 613-618, 2013

21. Liu KC, Yen CY, Wu RS, Yang JS, Lu HF, Lu KW, Lo C, Chen HY, Tang NY, Wu CC and Chung JG: The roles of endoplasmic reticulum stress and mitochondrial apoptotic signaling pathway in quercetin-mediated cell death of human prostate cancer PC-3 cells. Environ Toxicol 29: 428-439, 2014.

22. Lin M-C, Tsai S-Y, Wang F-Y, Liu F-H, Syu J-N and Tang F-Y: Leptin induces cell invasion and the upregulation of matrilysin in human colon cancer cells. Biomedicine 3: 174-180, 2013.

23. Iglesias-Guimarais V, Gil-Guinon E, Sanchez-Osuna M, Casanelles E, Garcia-Belinchon M, Comella JX and Yuste VJ: Chromatin collapse during caspase-dependent apoptotic cell death requires DNA fragmentation factor, $40-\mathrm{kDa}$ subunit-/caspase-activated deoxyribonuclease-mediated 3'-OH single-strand DNA breaks. J Biol Chem 288: 9200-9215, 2013.

24. Jiang L, Zhao MN, Liu TY, Wu XS, Weng H, Ding Q, Shu YJ, Bao RF, Li ML, Mu JS, et al: Bufalin induces cell cycle arrest and apoptosis in gallbladder carcinoma cells. Tumour Biol 35: 10931-10941, 2014.

25. Zhang DM, Liu JS, Tang MK, Yiu A, Cao HH, Jiang L, Chan JY, Tian HY, Fung KP and Ye WC: Bufotalin from venenum bufonis inhibits growth of multidrug resistant $\mathrm{HepG} 2$ cells through $\mathrm{G} 2 / \mathrm{M}$ cell cycle arrest and apoptosis. Eur J Pharmacol 692: 19-28, 2012.

26. Wu SH, Bau DT, Hsiao YT, Lu KW, Hsia TC, Lien JC, Ko YC, Hsu WH, Yang ST, Huang YP and Chung JG: Bufalin induces apoptosis in vitro and has Antitumor activity against human lung cancer xenografts in vivo. Environ Toxicol 32: 1305-1317, 2017.

27. Yin PH, Liu X, Qiu YY, Cai JF, Qin JM, Zhu HR and Li Q: Anti-tumor activity and apoptosis-regulation mechanisms of bufalin in various cancers: new hope for cancer patients. Asian Pac J Cancer Prev 13: 5339-5343, 2012.

28. Zhao H, Zhao D, Tan G, Liu Y, Zhuang L and Liu T: Bufalin promotes apoptosis of gastric cancer by down-regulation of miR-298 targeting bax. Int J Clin Exp Med 8: 3420-3428, 2015.

29. Hong SH and Choi YH: Bufalin induces apoptosis through activation of both the intrinsic and extrinsic pathways in human bladder cancer cells. Oncol Rep 27: 114-120, 2012.

30. Jing Y, Watabe M, Hashimoto S, Nakajo S and Nakaya K: Cell cycle arrest and protein kinase modulating effect of bufalin on human leukemia ML1 cells. Anticancer Res 14: 1193-1198, 1994

31. Numazawa S, Shinoki MA, Ito H, Yoshida T and Kuroiwa $Y$ : Involvement of $\mathrm{Na}^{+}, \mathrm{K}(+)$-ATPase inhibition in $\mathrm{K} 562$ cell differentiation induced by bufalin. J Cell Physiol 160: 113-120, 1994.
32. Liu K, Cang S, Ma Y and Chiao JW: Synergistic effect of paclitaxel and epigenetic agent phenethyl isothiocyanate on growth inhibition, cell cycle arrest and apoptosis in breast cancer cells. Cancer Cell Int 13: 10, 2013.

33. Chu YL, Ho CT, Chung JG, Raghu R, Lo YC and Sheen LY: Allicin induces anti-human liver cancer cells through the p53 gene modulating apoptosis and autophagy. J Agric Food Chem 61: 9839-9848, 2013.

34. Green DR and Fitzgerald P: Just so stories about the evolution of apoptosis. Curr Biol 26: R620-R627, 2016.

35. Li W, Zhao L, Wei T, Zhao Y and Chen C: The inhibition of death receptor mediated apoptosis through lysosome stabilization following internalization of carboxyfullerene nanoparticles. Biomaterials 32: 4030-4041, 2011.

36. Grunnet LG, Aikin R, Tonnesen MF, Paraskevas S, Blaabjerg L, Storling J, Rosenberg L, Billestrup N, Maysinger D and Mandrup-Poulsen T: Proinflammatory cytokines activate the intrinsic apoptotic pathway in beta-cells. Diabetes 58: 1807-1815, 2009.

37. Santin I, Moore F, Colli ML, Gurzov EN, Marselli L, Marchetti P and Eizirik DL: PTPN2, a candidate gene for type 1 diabetes, modulates pancreatic beta-cell apoptosis via regulation of the BH3-only protein Bim. Diabetes 60: 3279-3288, 2011.

38. Milutinovic S, Kashyap AK, Yanagi T, Wimer C, Zhou S, O'Neil R, Kurtzman AL, Faynboym A, Xu L, Hannum CH, et al: Dual agonist surrobody simultaneously activates death receptors $\mathrm{dr} 4$ and dr5 to induce cancer cell death. Mol Cancer Ther 15: 114-124, 2016.

39. Lin FL, Hsu JL, Chou CH, Wu WJ, Chang CI and Liu HJ: Activation of $\mathrm{p} 38$ MAPK by damnacanthal mediates apoptosis in SKHep 1 cells through the DR5/TRAIL and TNFR1/TNF-alpha and p53 pathways. Eur J Pharmacol 650: 120-129, 2011.

40. Chen Y, Azad MB and Gibson SB: Superoxide is the major reactive oxygen species regulating autophagy. Cell Death Differ 16: 1040-1052, 2009

41. Ip SW, Chu YL, Yu CS, Chen PY, Ho HC, Yang JS, Huang HY, Chueh FS, Lai TY and Chung JG: Bee venom induces apoptosis through intracellular $\mathrm{Ca}^{+}{ }^{+}$-modulated intrinsic death pathway in human bladder cancer cells. Int J Urol 19: 61-70, 2012.

42. Chiu TH, Lan KY, Yang MD, Lin JJ, Hsia TC, Wu CT, Yang JS, Chueh FS and Chung JG: Diallyl sulfide promotes cell-cycle arrest through the p53 expression and triggers induction of apoptosis via caspase- and mitochondria-dependent signaling pathways in human cervical cancer Ca Ski cells. Nutr Cancer 65: 505-514, 2013.

43. Tsai CW, Yang MD, Hsia TC, Chang WS, Hsu CM, Hsieh YH, Chung JG and Bau DT: Dithiothreitol enhanced arsenic-trioxide-induced cell apoptosis in cultured oral cancer cells via mitochondrial dysfunction and endoplasmic reticulum stress. Environ Toxicol 32: 17-27, 2015.

44. Mohan S, Abdelwahab SI, Kamalidehghan B, Syam S, May KS, Harmal NS, Shafifiyaz N, Hadi AH, Hashim NM, Rahmani M, et al: Involvement of NF-kappaB and $\mathrm{Bcl} 2 / \mathrm{Bax}$ signaling pathways in the apoptosis of MCF7 cells induced by a xanthone compound Pyranocycloartobiloxanthone A. Phytomedicine 19: 1007-1015, 2012

45. Ma YS, Hsu SC, Weng SW, Yu CC, Yang JS, Lai KC, Lin JP, Lin JG and Chung JG: Crude extract of Rheum palmatum L induced cell death in LS1034 human colon cancer cells acts through the caspase-dependent and -independent pathways. Environ Toxicol 29: 969-980, 2014.

46. Wu J, Tan Z, Chen J and Dong C: Cyclovirobuxine D inhibits cell proliferation and induces mitochondria-mediated apoptosis in human gastric cancer cells. Molecules 20: 20659-20668, 2015.

47. Chiang JH, Yang JS, Ma CY, Yang MD, Huang HY, Hsia TC, Kuo HM, Wu PP, Lee TH and Chung JG: Danthron, an anthraquinone derivative, induces DNA damage and caspase cascades-mediated apoptosis in SNU-1 human gastric cancer cells through mitochondrial permeability transition pores and Bax-triggered pathways. Chem Res Toxicol 24: 20-29, 2011. 